\title{
The distribution and conservation status of the Bearded Tachuri Polystictus pectoralis
}

\author{
N. J. COLLAR and D. C. WEGE
}

\section{Summary}

The Bearded Tachuri Polystictus pectoralis occupies lowland grasslands with scrubby vegetation, generally near water, in the Andean grasslands of Colombia at two sites (threatened race bogotensis), savannas in eastern Colombia and the lowland and tepui grasslands of mainly southern Venezuela, Guyana, Surinam, French Guiana and northern Brazil (race brevipennis), reappearing south of the Amazon in central-southern Brazil, eastern Bolivia (no recent records), Paraguay, Uruguay and northern and central-eastern Argentina (nominate pectoralis). It is an austral summer visitor (October/ November to February/April) to central-east Argentina, nesting (commonly in thistles) around December, clutch-size three. It feeds on insects by perch-gleaning, sallying, hover-gleaning and still-hunting. It is unobtrusive and must be commonly overlooked, and in some localities may be moderately well represented. Overall, however, it is scarce and appears to be very patchy in occurrence; grassland habitats within its range have been converted wholesale to farming. New quantitative criteria support earlier qualitative judgement that the species is probably not (yet) threatened, but that it merits near-threatened status. Suggestions that one or all of its three subspecies may be good species are premature; it is not even clear how distinct these forms are as subspecies.

\section{Introduction}

Habitats in South America other than tropical forests and wetlands have only relatively recently become a subject of serious concern in conservation. In particular, the natural grasslands of the continent have been badly neglected while attention has been focused on biologically richer habitats, with the result that vast areas of open country have been allowed and indeed encouraged to be converted to human food production with barely any recognition of their biological value.

These grasslands host a number of biome endemics, sometimes wide-ranging so that large areas of habitat are needed for their preservation (e.g. maned wolf Chrysocyon brachyurus and marsh deer Blastocerus dichotomus). Ornithologically, a broad suite of species depends to some extent on Neotropical grasslands. As many as 38 of them were recently listed as threatened (Collar et al. 1992), representing $12 \%$ of all threatened New World species (Collar et al. in press). In addition, several species were listed as "near-threatened", notably those whose centre of occurrence lies in the grasslands of interior south-east Brazil, Paraguay, Argentina and in some cases eastern Bolivia, for example Cock-tailed Tyrant Alectrurus tricolor, Sharp-tailed Grass-tyrant Culicivora caudacuta and Black-masked Finch Coryphaspiza melanotis (see, e.g., Collar et al. 1992: 795). 
Concern expressed over the plight of the Bearded Tachuri Polystictus pectoralis, "a tiny, buffy flycatcher found very locally in tall grass areas [which] may well deserve threatened status" (Ridgely and Tudor 1994), caused its listing in a preliminary treatment of globally threatened birds (Collar and Andrew 1988). Ted Parker strongly shared that concern and, as a co-author of the fuller evaluation of New World species (Collar et al. 1992), he prepared some notes to support its continued listing. We duly assembled the evidence, through a review of all published sources, accumulation of data from specimens in as many museums as possible (see Appendix), and extensive correspondence with fieldworkers familiar with the species and its habitat (recently supplemented by an appeal for records made in Cotinga $1: 48$ ). We concluded that its status was not yet so severe as to warrant retention of threatened status, treating it instead as near-threatened (Collar et al. 1992), a judgement which held when all New World species were recently re-evaluated against new criteria (Collar et al. 1994). However, as with many other near-threatened species, we were left with an extensive body of material on the bird, much of it unpublished and all of it, if arranged properly, capable of providing a baseline dataset for current and future evaluation and monitoring of its status. In homage to Ted Parker, whose voice was amongst the first and loudest to be raised in alarm at the plight of South American grasslands, we offer this dataset here.

Museum initials used in the following account are given in the Appendix, and an explanation of the use of the asterisk $\left({ }^{*}\right)$ appears in the legends to Figures 2 and 3 .

\section{Distribution}

The Bearded Tachuri has a disjunct distribution in South American grasslands either side of the Amazon basin. To the north it has been found in one or two highland areas of western Colombia (race bogotensis), and in the lowland savannas of eastern Colombia eastwards through central Venezuela into the tepui region of southern Venezuela, Guyana, and northern Brazil, with isolated populations in southern Surinam and northern French Guiana (race brevipennis). South of the Amazon it reappears in the nominate form, ranging through southern Brazil, eastern Bolivia, Paraguay, Uruguay and the northern half of lowland Argentina. The records that allow us to compose this generalized assessment (see Figure $x$ ) are set out below, arranged in sequences within and by the major subnational political divisions (states, departments, provinces; except for the Guianas) from west to east and/or north to south, with numbers in Figures 2 and 3 corresponding to superscript numbers in the text.

\section{Polystictus pectoralis bogotensis}

Colombia (Cundinamarca) This form is known with certainty only from Suba marshes ${ }^{1}, 2,711 \mathrm{~m}$, in what are now the northern suburbs of Bogotá (Cory and Hellmayr 1927, Paynter and Traylor 1981). Hilty and Brown (1986) say "once" from this site, but this cannot be correct since the type-specimen was collected 


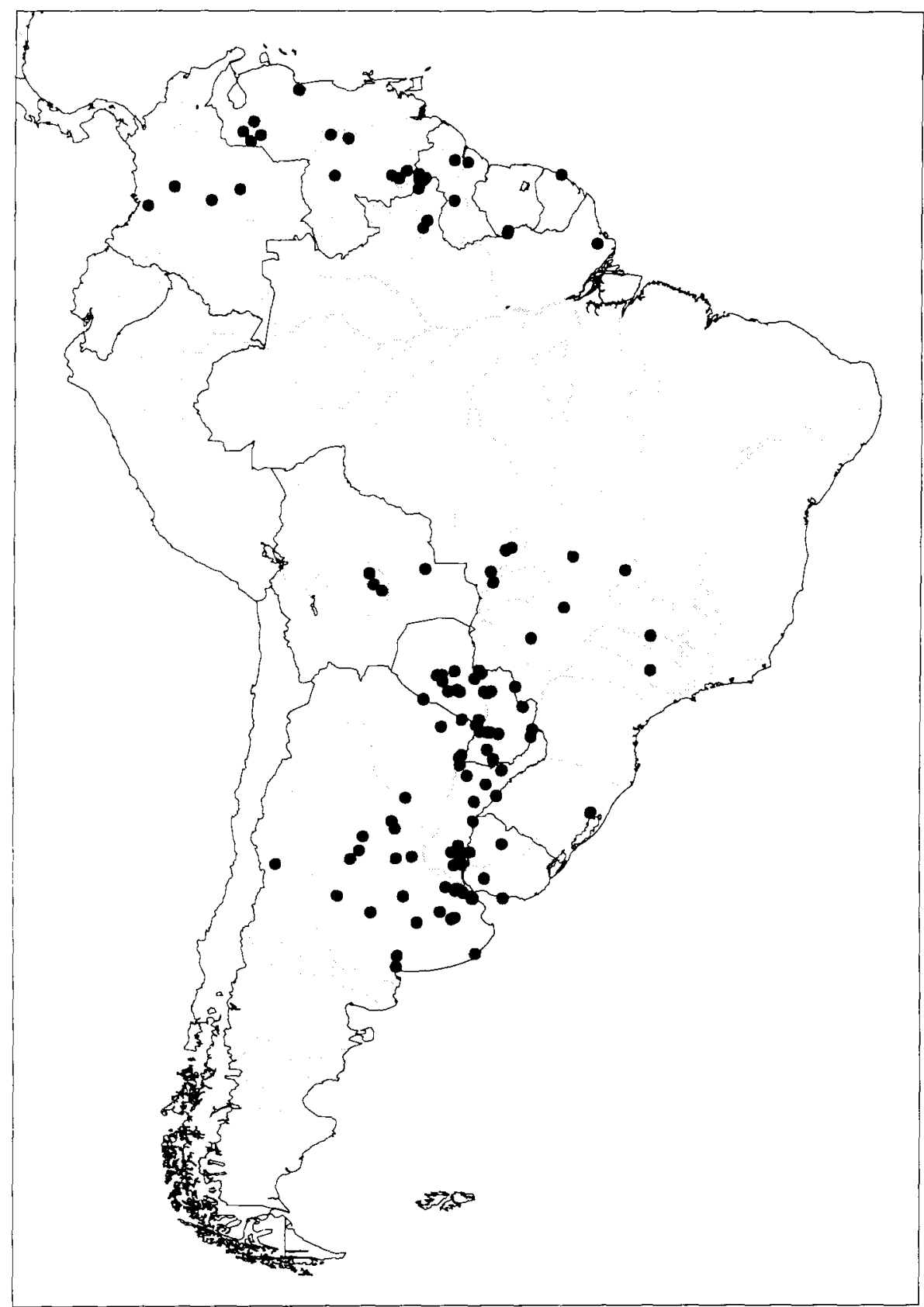

Figure 1 . The distribution of the Bearded Tachuri throughout its range, based on records assembled in the text.

in April 1915 (Chapman 1915) and there is a specimen dated January 1917 in AMNH and another from April 1919 in USNM, plus a specimen simply labelled Bogotá, taken on 19 March of an unspecified year, in MCZ; moreover, there are apparently two specimens in Museo de la Salle, Bogotá, dating from the 1950 
(F. G. Stiles in litt. 1994). (Valle) A specimen from Pavas², La Cumbre, above Dagua at $1,350 \mathrm{~m}$ on western slope of the West Andes, taken in July 1918, was assumed to belong to the race bogotensis (Cory and Hellmayr 1927; specimen in $\mathrm{CM}$ ) and has subsequently entered the literature as such (Hilty and Brown 1986, Fjeldså and Krabbe 1990, Ridgely and Tudor 1994; but see Taxonomy below).

\section{Polystictus pectoralis brevipennis}

Colombia (Meta) Only two areas are so far documented, in the north-west and north-east (Hilty and Brown 1986): $16 \mathrm{~km}$ south of Puerto López ${ }^{3}$, December 1971 (specimen in ANSP), and (clearly the same or adjacent locality) at Laguna Mozambique, $14 \mathrm{~km}$ south and $10 \mathrm{~km}$ east of Puerto López, February 1970 (two specimens in ANSP), with one seen there in January 1993 (F. G. Stiles in litt. 1994); and Carimagua ${ }^{4}, 150 \mathrm{~m}$, May and June 1976 (four specimens in FMNH, IND), where birds were present in small numbers in November 1993 (F. G. Stiles in lit: 1994).

The species is expected to occur in adjacent Vichada and also Arauca (Hilty and Brown 1986).

Venezuela (Carabobo) El Paíto, near Valenciā (museum specimen of unknown date reported by C. Parrish in litt. 1986 to R. S. Ridgely; also Ridgely and Tudor 1994); (Barinas) Santa Bárbara ${ }^{6}$ and Ciudad Bolivia ${ }^{7}$ (Phelps and Phelps 1963); (Apure) Guasdualito and Palmarito ${ }^{9}$ (Phelps and Phelps 1963); (Amazonas) El Platanal $^{10}$ (Phelps and Phelps 1963); (Bolivar) Quiribana de Caicara ${ }^{11}$ (type-locality), Río Orinoco, April 1898 (von Berlepsch and Hartert 1902); Maripa $^{12}$, Río Caura, October and December 1909 (two specimens in CM; also Cory and Hellmayr 1927), a locality now known to visiting birdwatchers, with 3-4 being seen there in late February 1994 (B. E. Wright in litt. 1994); $\mathrm{km} 200$ on El Dorado-Santa Elena road, Canaima ${ }^{13}$ National Park, February 1991 (R. Hopf in litt. 1994); Urimán ${ }^{14}$ (Phelps and Phelps 1963); Acopán-tepuî́15 (Phelps and Phelps 1963); Kanavayén ${ }^{16}$ (Kabanayén) (Phelps and Phelps 1963), whence also a record in the early 1980s (M. L. Goodwin in litt. 1992); Santa Elena de Uairén $^{17}$, $960 \mathrm{~m}$, January 1950 (specimen in COP; also Phelps and Phelps 1963); female-plumaged bird, ${ }^{*}$ Quebrada Pacheco ${ }^{18}, \mathrm{~km} 236$ on road to Santa Elena through the Gran Sabana, April 1994 (M. Kessler in litt. 1994); $4 \mathrm{~km}$ west of ${ }^{*}$ Peraitepuí ${ }^{19}$ on the road from San Francisco de Yuruanu to Peraitepui, $900 \mathrm{~m}$, in the Gran Sabana, April 1994 (M. Kessler in litt. 1994); Cerro Roraima 20, November and December 1881, June, October, November and December 1883 , and October 1898 (12 specimens in ANSP, BMNH, USNM, at least three of which were collected at $1,060 \mathrm{~m}$; also Salvin 1885, Sclater 1888, Phelps and Phelps 1963), including Paulo, October and November 1927 (Chapman 1931; three specimens in $\mathrm{AMNH}$ ).

Guyana (Roraima specimens are treated as stemming from the Venezuelan sector above: see Stephens and Traylor 1985.) Upper Takutu Mountains ${ }^{21}$, 1908 (two specimens in AMNH, BMNH; also Chubb 1921); Annai ${ }^{22}$, May and June 1890, February 1891 and June 1892 (seven specimens in AMNH, ANSP); two miles 


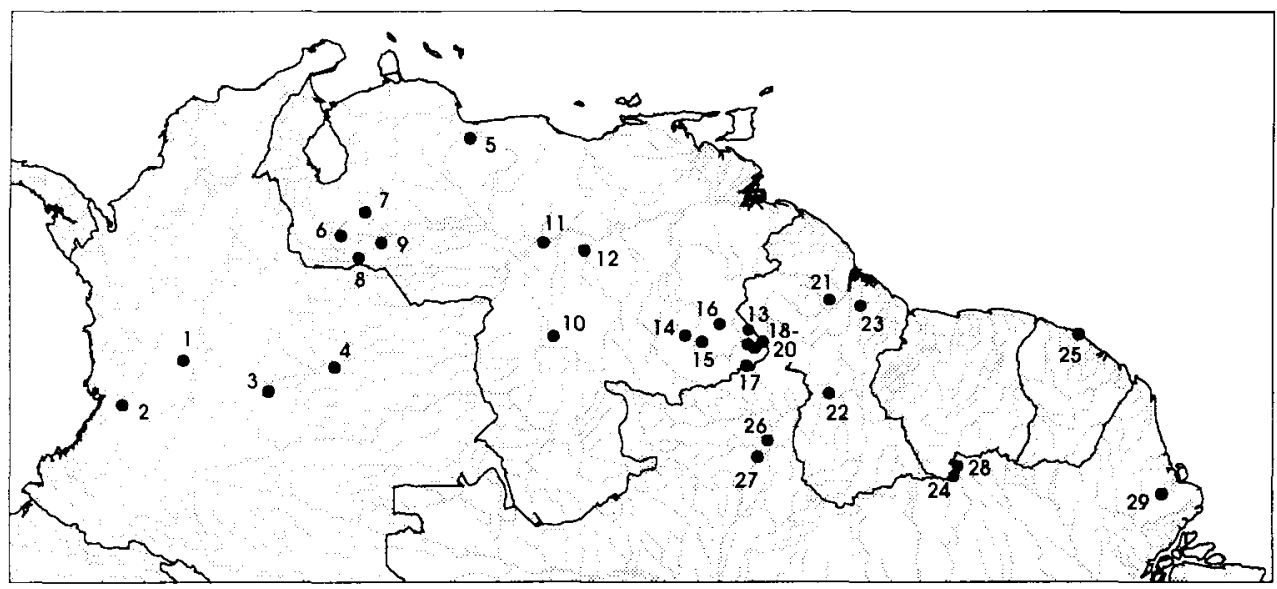

Figure 2. The distribution of the Bearded Tachuri, subspecies bogotensis and brevipennis. Numbers by locality points correspond to those in the text under Distribution. Coordinates for these localities are derived from Paynter (1982), Paynter and Traylor (1981, 1985, 1991), Stephens and Traylor (1985), or else The Times aflas of the world (seventh edition). Localities not in these sources are marked in the text with an asterisk $\left(^{*}\right)$ and are as follows, with sources for their coordinates as shown: Quebrada Pacheco, c. $5^{\circ} 08^{\prime} \mathrm{N}$ $61^{\circ} 06^{\prime} \mathrm{W}$ (M. Kessler in litt. 1994); Peraitepuí, c. $5^{\circ} 03^{\prime} \mathrm{N} 60^{\circ} 56^{\prime} \mathrm{W}$ (M. Kessler in litt. 1994).

east of Linden ${ }^{2.3}$ Highway about 15 miles south of that highway's northern terminus, August 1993 (R. Ryan in litt. 1994).

Surinam Sipaliwini ${ }^{24}$, male taken January 1966 (Mees 1968) with an apparent female in May 1972 (Haverschmidt and Mees 1994; specimens in RMNH).

French Guiana Sinnamary ${ }^{25}$, November 1986 and March 1989 (three specimens in CMN). Neither of these records was known to Tostain et al. (1992), who however mentioned records from this locality (qualifying it as "la savane des Pères") in December 1987 and a few months later, plus another in the savane de Coumbi-Sinnamary in July 1991.

Brazil (Roraima) Fazenda Santa Cecilia, opposite Boa Vista ${ }^{26}$ on the east side of the Rio Branco, February and March 1992 (D. F. Stotz in litt. 1995); Rio Mucajaí ${ }^{27}$, south of Boa Vista, April 1962 (specimen in MZUSP; also Pinto 1966) and March 1963 (specimen in MPEG; also Novaes 1967); (Pará) Cabaceiras do rio Paru de Oeste, Posto Tiriós ${ }^{28} 340 \mathrm{~m}$, June 1960 (at least three specimens in MNRJ, MPEG; also Novaes 1967); (Amapá) Acampamento no. 4, igarapé Ariramba, right-bank affluent of Rio Tartarugal ${ }^{29}$, July 1969 (two specimens in MPEG; also Novaes 1978).

\section{Polystictus pectoralis pectoralis}

Brazil (Goiás) Aragarças ${ }^{30}$, June 1953 (specimen in MNRJ; locality also specified by Sick 1993); Goiânia ${ }^{31}$, September 1967 (specimen in MPEG); Emas National 
Park ${ }^{32}$, 1980-1992, including the months of September and October (R. S. Ridgely, T. A. Parker in litt. 1992; also R. Schofield in litt. 1994), and just outside, August 1989 (R. Schofield in litt. 1994); (Mato Grosso) Chapada dos Guimarães ${ }^{33}$ ("Chapada"), August 1882 (two specimens in AMNH), July and September 1883 (specimens in AMNH and MNRJ respectively) and May to September 1885 (seven specimens in AMNH, BMNH, MCZ; also Allen 1892); Cuiabá ${ }^{34}$, July presumably of 1824 (specimen in BMNH; von Pelzeln 1868-1871, Sclater 1888) and again in September 1993 by the airport (A. Whittaker in litt. 1994); Porto Jofre $^{35}$, Transpantaneira, August 1988 (R. Fairbank and N. Preston per B. C. Forrester in litt. 1994), and north of Porto Jofre, August 1991 (T. A. Parker in litt. 1992); (Mato Grosso do Sul) *Passo do Lontra ${ }^{36}$, August 1991 (J. F. Pacheco verbally 1992 to L. P. Gonzaga); Campo Grande ${ }^{37}$, July 1930 (seven specimens in MCZ, MZUSP), and the nearby Fazenda Curralinho, September 1938 (specimen in MZUSP; also Pinto 1944), with several singletons south of Campo Grande, June 1983 (R. S. Ridgely in litt. 1995); near ${ }^{*}$ Pixaim ${ }^{38}$ along the Transpantaneira road, Pantanal, in September 1992 (K. Zimmer and T. A. Parker per A. Whittaker in litt. 1994); (São Paulo. Calção do Couro ${ }^{39}$, April 1823 (von Pelzeln 1868-1871), now within a suburb of Ituverava (Collar et al. 1992: 759); Estação Ecológica Estadual de Itirapina, near Itirapina ${ }^{40}, 760 \mathrm{~m}$, January 1992 (Willis 1992) and December 1993 (R. S. Ridgely, D. K. Dacol in litt. 1994); and at least one other locality in the past 20 years (E. O. Willis in litt. 1986); (Rio Grande do Sul) Itaquíi ${ }^{41}$. November 1914 (specimen in MZUSP; also Pinto 1944); Porto Alegre ${ }^{42}$, unknown date (Gliesch 1930).

Bolivia (Santa Cruz) Buena Vista43, "Prov. Sara", July 1912 (Cory and Hellmayr 1927); Santa Cruz" ("Santa Cruz de la Sierra"), August and September 1909 (Cory and Hellmayr 1927; six specimens in CM and in YPM); "Campa, $700 \mathrm{~m}$, Prov. Sara" (i.e. Provincia Gutiérrez ${ }^{45}$ ), October 1908 (specimen in AMNH; also Zimmer 1955); probably also Santa Ana" ("Santa Ana, Chiquitos"), which is the type-locality of Muscicapa stramineoventris Lafresnaye and d'Orbigny 1837, the type material for which is apparently lost but whose description strongly suggests the immature plumage of and hence synonymy with $P$. p. pectoralis (Hellmayr 1925; also Cory and Hellmayr 1927).

Paraguay (Boquerón) Orloff ${ }^{47}$ (Colonia Mennonita), October 1945 (specimen in FMNH); (Presidente Hayes) $235 \mathrm{~km}$ west of ${ }^{*}$ Riacho Negro ${ }^{48}$, July and August 1939 (five specimens in UMMZ); Laguna Escalante ${ }^{49}$, August 1960 (Steinbacher 1962); Villa Militar ${ }^{50}$, July 1945 (FMNH); Lichtenau ${ }^{51}$, February (year unclear), August and October 1971 (Short 1976; three specimens in AMNH); Laguna General Díaz ${ }^{52}$, July 1945 (FMNH); $20 \mathrm{~km}$ east of Pozo Colorado ${ }^{53}$, September 1989 (two specimens in MHNG); Makthlawaiya ${ }^{54}$, March 1931 (specimen in AMNH; also Zimmer 1955); Puerto Pinasco ${ }^{55}$, Río Paraguay, September and October 1916 (two specimens in AMNH; also Zimmer 1955) and September 1920 (two specimens in USNM; also Cory and Hellmayr 1927); Benjamin Aceval ${ }^{56}$, undated (Bertoni 1930); west bank of Río Paraguay, across the river from Concepción $^{57}$, May 1989 (F. E. Hayes in litt. 1994); (Concepción) Estancia Centurión" ${ }^{58}$, May 1989 (F. E. Hayes in litt. 1994); San Luis de la Sierra" ("La Fonciere"), May 1931 (Zimmer 1955; four specimens in AMNH); Belén ${ }^{60}$, Rio 
Ypané, August 1930 (Zimmer 1955; specimen in AMNH); Horqueta ${ }^{61}$, July to October 1935 (specimens in ROM, UMMZ); (Amambay) Cerro Amambay ${ }^{62}$, September 1938 (UMMZ); (Canindeyú) Lagunita, Reserva Natural del Bosque Mbaracayú $^{63}$, September 1992 (Brooks et al. 1993); (Alto Paraná) open areas of ${ }^{*}$ Reserva Tatí Jupi ${ }^{64}$, just north of Ciudad del Este, a few times in the 1980s (N. Perez in litt. 1988 to L. P. Gonzaga); (Guairá) Villarrica ${ }^{65}$, July 1924 and July 1925 (two specimens in BMNH); (Central) Nueva Italia ${ }^{66}$, July and August 1940 (three specimens in $\mathrm{AMNH}$ ); ${ }^{*}$ Bernal-cué ${ }^{67}$, near Asunción (undated but probably nineteenth century specimen in ZSM; site mentioned by Cory and Hellmayr 1927 but untraced by Paynter 1989); (Paraguari) Sapucaí ${ }^{68}$, March 1904 (Chubb 1910); Escobar ${ }^{69}$, May and June 1908 (two specimens in MACN); Paraguarí ${ }^{70}$, in the period late June to mid-August 1893 (Salvadori 1895); (Misiones) $20 \mathrm{~km}$ west of San Juan Bautista ${ }^{71}$, August 1994 (F. E. Hayes in litt. 1994); 5 km north-west of Santiago ${ }^{72}$, March 1989 (F. E. Hayes and J. L. Ramírez in litt. 1994).

Uruguay (Artigas) San Gregorio ${ }^{73}$ (Cuello and Gerzenstein 1962); (Tacuarembó) Pozo Hondo ${ }^{74}$, April 1958 (specimen in MNHNM; referred to by Cuello and Gerzenstein 1962); (Paysandú) Paysandú ${ }^{75}$, November 1883 (specimen in BMNH; also Gibson 1885 , Sclater 1888); (Soriano) Santa Elena ${ }^{76}$, Río Monzon, November 1892 (two specimens in BMNH; see Aplin 1894); (Montevideo) Montevideo ${ }^{77}$, austral summer 1831-1832 (Gould 1841).

Argentina (Formosa) Comandante Fontana ${ }^{78}$, September 1929 (specimen in AMNH); Clorinda ${ }^{79}$, San José, October 1925 (specimen in ZSM); ${ }^{*}$ Espinillo ${ }^{80}$, in the north-east of the province, July 1988 (B. M. López Lanus in litt. 1991); (Chaco) Las Palmas ${ }^{81}$, Río Quia, July 1920 (specimen in USNM; see Wetmore 1926); *Irarana ${ }^{82}$, March possibly of 1860 (specimen in USNM; see Remark 2 in Collar et al. 1992: 795); (Misiones) Arroyo Urugua-1 ${ }^{83}, \mathrm{~km}$ 10, April 1952 (a young male in a clearing in the San Martín maté plantation near Puerto Bemberg) (Partridge 1954), April 1958 (Navas and Bó 1988, who mention three specimens, with a further seven in AMNH), July and August 1958 (five specimens in AMNH) and June 1961 (specimen in YPM); (Corrientes) Santa Ana ${ }^{84}$, January 1987 (Environmental Investigation Agency in Pearman and Abadie 1995); Estancia San Joaquin ${ }^{85}$, San Carlos, Río Aguapey, July 1961 (two specimens in AMNH, LSUMZ); present in 1989 in the area of the new Mburucuyá ${ }^{86}$ National Park (M. A. E. Rumboll per J.-C. Chebez in litt. 1992); Laguna Iberá87, April 1990 (B. M. López Lanus in litt. 1991); Estancia Rincón del Ombú ${ }^{88}$, Mercedes, October 1961 (specimen in AMNH); (Entre Ríos) Arroyo Barú ${ }^{89}$, January 1993 (M. Nores in litt. 1995); ${ }^{*}$ Ruta Nacional $12^{90}, 9 \mathrm{~km}$ south of the junction with Ruta Provincial 6, February 1993 (female with two dependent immatures: Pearman and Abadie 1995); Pronunciamento ${ }^{91}$, December 1970 (nesting pair with young: T. Narosky in Pearman and Abadie 1995); La Soledad ${ }^{92}$, December 1898, October 1901, February 1902 (Hartert and Venturi 1909; three specimens in AMNH); Gualeguaychú ${ }^{93}$, December 1959 (Camperi 1992); outside * Larroque $^{94}$, February 1993 (one immature netted: Pearman and Abadie 1995); (Santa Fe) Estancia El Orden, Tostado ${ }^{95}$, October 1938 (specimen in MACN); Estancia La Germania $^{96}$, Las Rosas, July 1925 (specimen in ZSM); (Córdoba) Bañados del Río Dulce $^{97}$ (Nores and Yzurieta 1980, Nores et al. 1983); south coast (Altos de 
Chipión and Desembocadura del Río Segundo) of Mar Chiquita ${ }^{98}$ (Nores and Yzurieta 1980, Nores et al. 1983, M. Nores and D. Yzurieta in litt. 1986); near Córdoba $^{99}, 1879$ (specimen in BMNH; also Cabanis 1878 , Sclater 1879 , Sclater 1888, Sclater and Hudson 1888); Embalse ${ }^{100}$ (de Río Tercero), where nesting has been recorded (Nores and Yzurieta 1980, Nores et al. 1983, M. Nores and D. Yzurieta in litt. 1986), this presumably being the source of the record from the district of Calamuchita (Canevari et al. 1991); Leones ${ }^{101}$, January 1949, October 1950, January 1961 (five specimens in MACN) and February 1989 (Pearman and Abadie 1995); Sierra de Comechingones ${ }^{102}$ at 1,600 m, on the road to Atos Pampa (Nores and Yzurieta 1980, Nores et al. 1983), this possibly being the area called the Sierra de Córdoba by Cabanis (1878); (Buenos Aires) (records here are based chiefly on the maps - including that showing the partidos, or districts - in Narosky and di Giacomo 1993) San Antonio de Areco ${ }^{103}$; Escobar, presumably at Zelaya ${ }^{104}$ (Pereyra 1923, 1938; also three specimens in MACN dated April 1922, October 1945 and - a juvenile - January 1946), with the species now listed for the Otamendi National Scientific Reserve (see Chebez et al. in press); ${ }^{*}$ Benavídez $z^{105}$, west of Tigre (B. M. López Lanus in litt. 1991); Pilar ${ }^{106}$; Capital Federal ${ }^{107}$, i.e. Buenos Aires (a female seen in November 1990: M. Babarskas in litt. 1992), in two cases specifying Costanera del Sur, in October 1986 (B. M. López Lanus in litt. 1991) and in November 1992 (R. Schofield and H. W. Wallis in litt. 1994); ${ }^{*}$ Estancia Santa Elena (see note below) ${ }^{108}$, November 1892 (two specimens in BMNH; Holland 1893); General Pinto ${ }^{109}$; Enseñada (Punta Lara ${ }^{110}$ : Klimaitis and Moschione 1987); La Plata (La Plata ${ }^{111}$ town, February 1919 and November 1946: two specimens in UNP and MACN respectively); Berisso ${ }^{112}$ (nesting recorded at a date between 1967 and 1970: M. Nores and D. Yzurieta in litt. 1986); Saladillo ${ }^{133}$ (two nests in December 1985: B. M. López Lanus in litt. 1991); Las Rosas ${ }^{11}$, November 1917 (Daguerre 1922; specimen in MACN); Las Flores ${ }^{115}$; Bolívar ${ }^{116}$ (August 1947: specimen in MACN); General Pueyrredón (presumably at Chapadmalal ${ }^{117}$ : see Martelli 1989); Saavedra (i.e. serranías de Curamálan, Piguié $e^{118}$, November 1988: Narosky et al. 1990); Tornquist ${ }^{119}$; Bahia Blanca ${ }^{120}$, November 1899 and October 1900 (Hartert and Venturi 1909; two specimens in AMNH), and November 1910 (specimen in ZSM); (La Pampa) General Pico ${ }^{121}$, December 1935 (specimen in MACN; hence the listing of the province in SOMA 1935-1942); (Mendoza) Potrerillos ${ }^{122}, 1,500 \mathrm{~m}$, March 1921 (Peters 1923; specimen - a juvenile - in MCZ); (Santiago del Estero) listed by SOMA (1935-1942), hence doubtless in Olrog (1979) and Ridgely and Tudor (1994), but not mentioned by Nores et al. (1991), although M. Nores in litt. (1995) suspects it may yet be found in the extreme south-east on land formerly within Córdoba province.

The position of Estancia Santa Elena Paynter (1985) cited addresses in Ibis to indicate that this locality is not in Entre Ríos, as has repeatedly been assumed. These addresses variously mention an estancia called Media Luna "40 miles south of Soler", and "Estancia Sta. Elena, Halsey", etc., on the Pacific railway. In a map (Lopez 1898) Soler appears on the railway line to San Luis and Mendoza in the middle of the section that traverses southernmost Santa Fe, so that "40 miles south" lies inside Buenos Aires province, where indeed there is a farm named Media Luna just north of a station called Halsey on another railway running west from Buenos Aires city to the junction of the borders of 
Córdoba and La Pampa. Comparison with The Times atlas of the world suggests that Halsey is now Ameghino and the position of Media Luna, which must either have been a synonym or neighbour of Estancia Santa Elena, should lie close to the present-day Santa Eleonora at $34^{\circ} 43^{\prime} \mathrm{S} 62^{\circ} 40^{\prime} \mathrm{W}$.

\section{Habitat}

The habitat of the Bearded Tachuri has been described in numerous ways, all qualitative in nature and (other than in the synthesizing literature) local in focus. The elevations are varied but, apart from the Suba marshes record of bogotensis $(2,711 \mathrm{~m})$ and two records from the Andean foothills in western Argentina $(1,600 \mathrm{~m}$ and $1,500 \mathrm{~m}$ ), all are from below $1,350 \mathrm{~m}$ (the altitude of the other bogotensis record and the upper limit for tepui localities), with the lowest stated elevation being $150 \mathrm{~m}$.

From Meta, Colombia, there are two accounts of the habitat. According to one, the species is found in open savanna with scattered bushes and tall clumped grass (Andropogon sp.) and weeds (S. Furniss in Hilty and Brown 1986). In the other, birds have been seen in grassy drainage ditches and on the grassy fringes of ponds (F. G. Stiles in litt. 1994).

For Venezuela the only published account refers to "swampy places in low, open woodland, forest edge, savannas to $200 \mathrm{~m}$ north of the Orinoco, to $1,300 \mathrm{~m}$ on the slopes of the tepuis" (Meyer de Schauensee and Phelps 1978). However, in the Gran Sabana the species is "found primarily in well-drained tall grassland with abundant shrubby growth, usually within a few hundred metres of forest", with birds "apparently rare or absent from more open grasslands that are frequently burnt" (T. A. Parker in litt. 1992). Nevertheless, near Peraitepuí in April 1994 the habitat was recently burnt open savanna on poor, sandy soil, with most vegetation only c. $20 \mathrm{~cm}$ high, although the birds were in or near a group of 10 or so small bushes $\mathrm{c} .70 \mathrm{~cm}$ high, while at Quebrada Pacheco the single bird observed was in a small $\left(300 \mathrm{~m}^{2}\right)$ patch of dense grassy vegetation between a river, a road and some riverine forest, this time with grasses $c .50 \mathrm{~cm}$ and bushes c.70 cm (M. Kessler in litt. 1994). At both sites the vegetation was composed primarily of Rhynchospora and Paepalanthus with scattered bushes, and, since the species was not found during several weeks spent in one area of grassy savanna from which bushes were absent, it was speculated that the Bearded Tachuri requires scattered bushes within open grassy savannas (M. Kessler in litt. 1994).

In French Guiana the habitat is "high grass on wet soils in savannas" (Tostain et al. 1992), while in Surinam the species has been found in "tussock grassland and low scrub" (Haverschmidt and Mees 1994); G. F. Mees (verbally 1995) commented that he expected to find it in grassy areas where bushier vegetation grew on damper (seasonally wet) ground, but he did not encounter it in the Rupununi savanna of southern Guyana, which was much wetter and perhaps more damaged by cattle.

In Brazil brevipennis occurs in the campos (open savannas) north of the Amazon, and in the campo-cerrado (grassland/savanna) region to the south. Specimen label data refer to "campo lavrado" (a local term for ploughed land) in Roraima (MPEG) and "capim jaraguá" (a species of grass Hyparrhenia rufa 


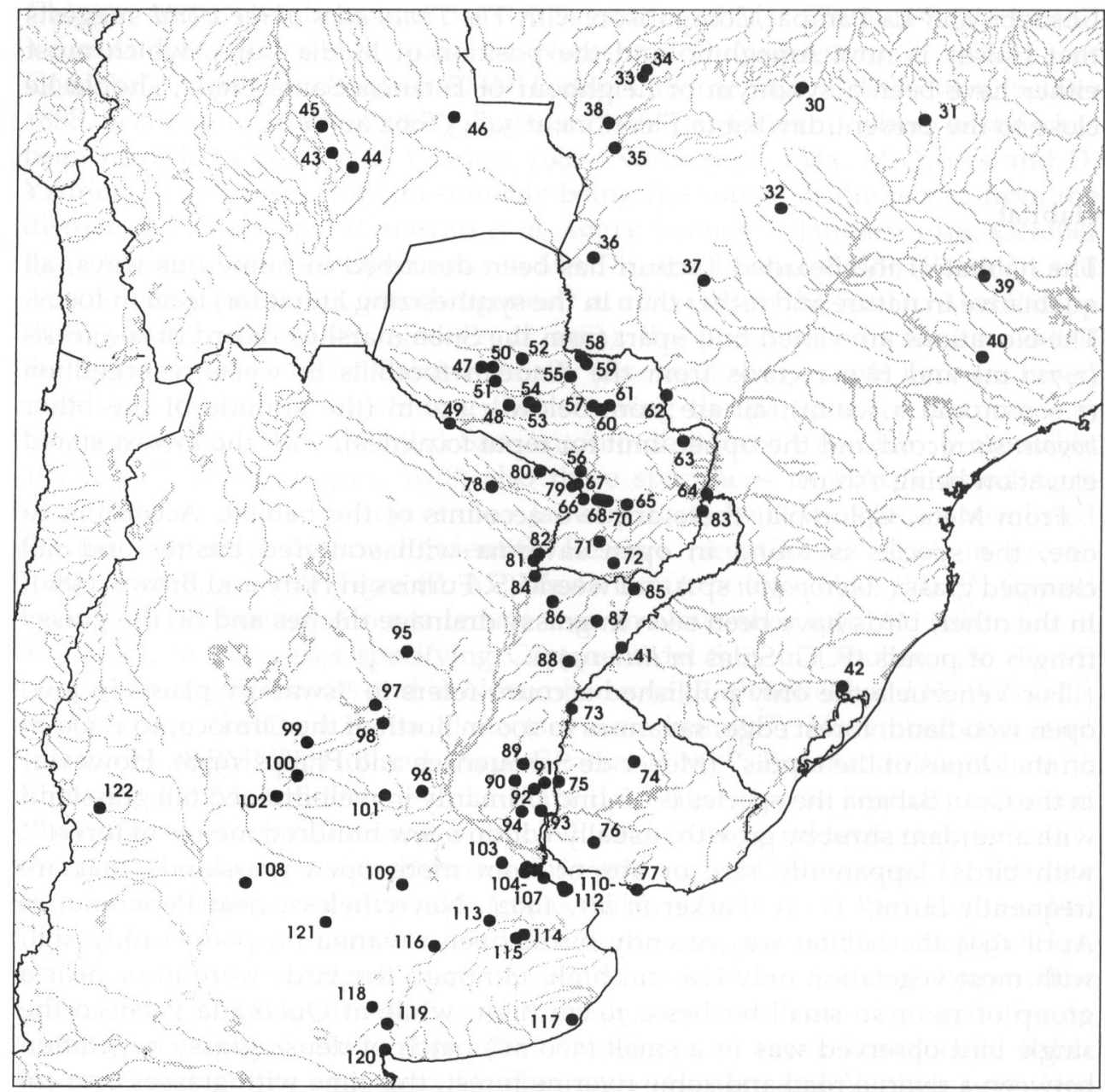

Figure 3. The distribution of the Bearded Tachuri, subspecies pectoralis. Numbers by locality points correspond to those in the text under Distribution. Coordinates for these localities are derived from Paynter (1985, 1989, 1992, 1994), Paynter and Traylor (1991), or else The Times atlas of the world (seventh edition). Localities not in these sources are marked in the text with an asterisk $\left(^{*}\right)$ and are as follows, with sources for their coordinates as shown: Pixaim, $16^{\circ} 45^{\prime} \mathrm{S} 56^{\circ} 57^{\prime} \mathrm{W}$ (Office of Geography 1963); Passo do Lontra, very roughly $19^{\circ} 40^{\prime} \mathrm{S} 57^{\circ} 20^{\prime} \mathrm{W}$ (based on information from L. P. Gonzaga in litt. 1995); Riacho Negro, $23^{\circ} 24^{\prime} \mathrm{S} 57^{\circ} 20^{\prime} \mathrm{W}$ (Office of Geography 1957); Reserva Tatí Jupí, $25^{\circ} 30^{\prime} \mathrm{S}$ $54^{\circ} 30^{\prime} \mathrm{W}$ (read from IUCN 1992); Bernal-cué, assumed to be in Central since known to be near Asunción (Paynter 1989), hence placed at $25^{\circ} 16^{\prime} \mathrm{S} 57^{\circ} 40^{\prime} \mathrm{W}$; Espinillo, $24^{\circ} 5^{\prime} \mathrm{S}$ $58^{\circ} 34^{\prime} \mathrm{W}$ (Office of Geography 1968); Ruta Nacional 12 at $32^{\circ} 18^{\prime} \mathrm{S} 59^{\circ} \mathrm{Og} \mathrm{g}^{\prime} \mathrm{W}$ (Pearman and Abadie 1995); Larroque, $33^{\circ} \mathrm{O} 2^{\prime} \mathrm{S} 58^{\circ} 59^{\prime} \mathrm{W}$ (Pearman and Abadie 1995); Benavídez, $34^{\circ} 25^{\prime} \mathrm{S}$ $58^{\circ} 40^{\prime} \mathrm{W}$ (M. Pearman in litt. 1995); Estancia Santa Elena, $34^{\circ} 43^{\prime} \mathrm{S} 62^{\circ} 40^{\prime} \mathrm{W}$ (see text). 
introduced from Africa) at Campo Grande (MZUSP). In Roraima in early 1992 (in the middle of the dry season) birds were present in a small, low-lying area of seasonally flooded, tall (up to $60 \mathrm{~cm}$ ), dense bunchgrass, close to a stream but with no bushes; no birds were found in adjacent very dry, heavily grazed campo grasslands (D. F. Stotz in litt. 1995). At Cuiabá in 1993 a bird was seen in wasteland adjacent to the airport approach road, near seasonally then very dry grassland and scrub (A. Whittaker in litt. 1994). In Emas National Park the species seems to be confined to tall grass and dense shrubbery along small streams through open grassland (T. A. Parker in litt. 1992). An individual seen in the Pantanal in western Mato Grosso was foraging in the tops of small bushes and in clumps of tall grass at the edge of a marsh (T. A. Parker in litt. 1992). At Itirapina birds are most numerous and breed in upland "campo sujo" (i.e. shrubby grassland) habitat, although single birds pass through disturbed, bushy pastures, especially in winter (E. O. Willis per T. A. Parker in litt. 1992).

In the chaco region Wetmore (1926) found the species "among weeds and low bushes in pastures not far distant from water", and Short (1975) characterized its habitat as open bushy country, including savannas, pampas, woodland edges and scrub desert, especially near water, including pantanal and the more open parts of chaco woodland. In Uruguay Aplin (1894) found his two specimens in "a belt of young plantation with undergrowth of grass, thistle, and other plants, joining the barley chacra".

In Argentina the species inhabits grasslands, secondary (i.e. weedy) herbaceous vegetation ("yuyales") and arid savannas with tall, hard grass ("pajonales") in the vicinity of lakes, marshes with reedbeds ("esteros") and flooded areas ("bañados") (Nores and Yzurieta 1980, Narosky and di Giacomo 1993), but also in fairly modified agricultural areas (even for nesting), which suggests that habitat alteration is not the main cause of its scarcity (M. Nores and D. Yzurieta in litt. 1986). Indeed, Partridge's (1954) specimen from 1952 in Arroyo Urugua-i was from an open area inside a maté plantation, while Pearman and Abadie (1995) have noted that in the north-east of the country the species seems to have colonized the borders of roads and railways, although M. Pearman accepts that its absence from many areas is a cause for concern: in general his records are from tall grasses and thistles Cynara cardunculus in areas of dry soil, but often adjacent to humid areas.

Two recent syntheses of all this information have been: "reed and rush-beds, and neighbouring grassland, thistles, bushes and trees" (Fjeldså and Krabbe 1990), and "savannas, tall grass in cerrado, lightly grazed fields, and adjacent shrubbery" (Ridgely and Tudor 1994). Both are clearly appropriate (the use of reeds and rushes is presumably inferred from the species's occurrence in habitat adjacent to "esteros"), but neither claims to identify the essence of Bearded Tachuri habitat. What seems to emerge from the notes and impressions amassed above is what Ted Parker wrote in his notes on the species, that Bearded Tachuris "inhabit a variety of types of grassland, all with varying amounts of shrubby vegetation" (our italics), a judgement that clearly mirrors the view of $M$. Kessler based on his experience in the Gran Sabana. However, D. F. Stotz's 1992 records from Roraima fail to fit this pattern, and R. S. Ridgely (in litt. 1995) has also questioned it. The other important factor appears to be water, the presence or proximity of which is repeatedly indicated by observers. This may, 
perhaps, simply be the factor that promotes different levels and types of vegetation in otherwise uninterrupted - and hence perhaps for the tachuri uninhabitable - grassland: Kessler's account of the Gran Sabana stresses its aridity, and R. S. Ridgely (in litt. 1995) has found the species far from water in both Emas and Itirapina. All the same, wet areas seem too recurrent a characteristic of Bearded Tachuri habitat (even if only when adjacent) to be discarded as of no significance to the species.

\section{Feeding, breeding and seasonality}

When foraging, the Bearded Tachuri will cling to grass stalks and perch-glean nearby surfaces (T. A. Parker in litt. 1992), but to describe it as a "strict perch-gleaner" (Fjeldså and Krabbe 1990) is mistaken. Birds make short sallies within grass to pick off insects, frequently changing perches but rarely flying far (Ridgely and Tudor 1994), and they regularly hover briefly to glean small insects from blades of grass and leaves of small bushes (T. A. Parker in litt. 1992, D. F. Stotz in litt. 1995). The Cuiabá airport bird was still-hunting, sallying to the ground from a perch $3 \mathrm{~m}$ up in a bush (A. Whittaker in litt. 1994). A bird near Leones, Córdoba, was likewise perch-hunting small caterpillars from the ground in an overgrown allotment, flying up to a low barbed-wire fence to eat them (M. Pearman verbally 1995). Stomachs of three birds collected in Roraima, early 1992, contained insect parts (D. F. Stotz in litt. 1995).

The assertion that the species is usually in pairs (Holland 1893. Fjeldså and Krabbe 1990) is contradicted by Ridgely and Tudor (1994), who report it as "usually seen singly, less often in pairs", but who add (see also R. S. Ridgely in Hilty and Brown 1986) that birds sometimes accompany flocks of other grassland birds such as grass-wrens Cistothorus, seedeaters Sporophila (especially Plumbeous Seedeater S. plumbea), Black-masked Finches Coryphaspiza melanotis and Sharp-tailed Grass-tyrants Culicivora caudacuta; another observer adds grassquits and spinetails (R. Schofield in litt. 1994). T. A. Parker (in litt. 1992) found them usually in pairs or in small family groups of three or four, and also noted their regular association with seedeaters and other small grassland insectivores.

The natural history notes provided from Argentina by Holland (1893) appear to have been neglected for over a century, but are worth reproducing for their insights on breeding activity: "These birds inhabit the quinta, and are of a very restless disposition before nesting, constantly hurrying from one weed-stalk to another in search of insects. They prefer long grass and weeds, and, as their flight is very low and straight, are hard to perceive. They live in pairs, and during the breeding season the male is most pugnacious, driving away from his nesting-place any stranger of the same species in a most determined way. On one's approaching the nesting-place the male has a peculiar habit of rushing up into the air some 20 feet, making a loud whirring noise (with its wings, I fancy) to intimidate the intruder; at other times it is very shy and easily escapes observation.

"The bird breeds at the beginning of November; the nest is cup-shaped, placed some inches off the ground in a clump of weeds, several stalks being interwoven in the structure, by which it is suspended. It is a minute bit of work, 
being 1 in. $\times 1$ in. deep in internal measurement, and composed of fine rootlets thickly lined and interwoven with grass-down, so that it has a white appearance. It is far superior to most nests in firmness and beauty. The eggs are three in number; they vary greatly in shape, but are of a uniform faint yellowish tinge in colour."

Holland's data on timing of breeding in Argentina and on nest structure and clutch-size are confirmed by Pereyra (1933, 1938) and Nores and Yzurieta (1980), who indicate that the nest is a small cup made of fine grass stems, rootlets, thistledown and spiders' webs, almost always placed in the "cardo negro" thistle Cirsium lanceolatum. The same seasonal pattern exists in São Paulo, where a pair was observed with two fledglings at Itirapina on 9 December $1984(\mathrm{E}$. O. Willis per T. A. Parker in litt. 1992), and in Misiones, for which at least two and possibly four of the seven April 1958 specimens in AMNH are juveniles.

North of the Equator the regime is different but less clearly known or defined. Examination of birds collected in February in Roraima, Brazil, confirmed that they were not breeding (D. F. Stotz in litt. 1995), yet the testes of a January male from Surinam were well developed while the organs of an adult specimen in May were so small as to be unfindable (specimens in RMNH). A pair in the Gran Sabana appeared to be behaving territorially in April (M. Kessler in litt. 1994). In Meta, Colombia, a male with testes $4 \times 2$ was collected in May (FMNH) followed in June by a male with testes $4 \times 3$ (IND), a juvenile female, skull unossified (FMNH), and a female (IND) with a shelled egg in her oviduct (as also reported in Hilty and Brown 1986); in December testes of a Meta specimen (ANSP) were $1.5 \times 1$, while the ovaries of one of two females (ANSP) were $4 \times 2$, and the bird was moulting. A male and female from Pará, June, were in moult (Novaes 1967), and testes of a male from Amapá, July, were $3 \times 2$ (Novaes 1978 ).

The species is described as resident in Hilty and Brown (1986), and there seems no reason to doubt that this is true of the short-winged brevipennis (see Taxonomy below). However, the claim that nominate pectoralis is non-migratory (Short 1975) is contradicted by a century of testimony from Argentina, starting with Holland (1893), who reported its arrival in October and departure in February, with confirmation provided by more recent observers (Daguerre 1922, Pereyra 1938, Nores and Yzurieta 1980, Nores et al. 1983, Narosky and di Giacomo 1993) - the first two of whom indicate November to March or April as the period of summer residence - not to mention the entire body of dated specimen material cited under Distribution.

The existence or pattern of seasonal displacement further to the north is less certain. Data from Misiones, Argentina, suggest a similar breeding season but possibly year-round residence (at any rate, specimens as late as April and as early as July). The dates of 10 specimens from Chapada dos Guimarães - two in May, two in July, four in August and two in September (Allen 1892) - might indicate the species's use of the area as a winter quarters, but may merely reflect chance or collecting intensity. It is, however, notable that all dates given above for nominate pectoralis from Brazil outside the southern states of São Paulo and Rio Grande do Sul are from May to October. Moreover, R. S. Ridgely (in litt. 1995) points out that his observations other than in São Paulo have usually been of single birds, and always of silent ones, which tends to accord with austral 
visitant status. If water is indeed significant in determining the distribution of the species, it may well be that its presence in the pantanal region is linked seasonally to the flooding regime there: the dry season causes the grasslands to be exposed from May to November, and the birds may then move in from the much drier surrounding areas.

\section{Population density, decline and threats}

Wherever it has been found, the Bearded Tachuri has been characterized as a scarce bird. Recent reviews (e.g. Fjeldså and Krabbe 1990, Ridgely and Tudor 1994) call it rare and local, and such judgement is repeated in many national and regional evaluations: "very local" in Colombia (Hilty and Brown 1986), "very scarce" on the Gran Sabana of south-eastern Venezuela (A. Altman and C. Parrish per/and T. A. Parker in litt. 1992), "scarce" in Sipaliwini, Surinam (Haverschmidt and Mees 1994), "scarce resident" in Uruguay (Gore and Gepp 1978), "definitely rare and perhaps endangered" in Paraguay (F. E. Hayes in litt. 1991), "scarce" in Córdoba (Nores and Yzurieta 1980, Nores et al. 1983), "rare" in Buenos Aires (Narosky and de Giacomo 1993), and "scarce and local" generally in Argentina (Pereyra 1933, M. Pearman in litt. 1990, T. A. Parker in litt. 1992).

Nevertheless, there are places where the species was and is reported in at least moderate numbers. Relatively recently it was judged fairly common in part of Meta, Colombia (S. Furniss in Hilty and Brown 1986). In Roraima, Brazil, it was "fairly common" (five birds collected and up to six seen in one day) in a small patch of appropriate habitat in early 1992 (D. F. Stotz in litt. 1995). In Córdoba, Argentina, there is a single area - Bañados del Río Dulce - where it is considered moderately frequent (Nores and Yzurieta 1980, Nores et al. 1983). At Itirapina in São Paulo state, Brazil, Willis (1992) reported six in one day, and R. S. Ridgely (in litt. 1994) recently found it more numerous than anywhere he had previously encountered it. It is possible that the relatively high representation of Guyanan specimens from Mount Roraima reflects fair numbers in pristine areas on isolated tepuis (T. A. Parker in litt. 1992); and the collection of seven specimens in July 1930 from Campo Grande in Brazil, and of 15 specimens in two short periods in 1958 at Arroyo Urugua-í, suggests locally solid populations. Conversely, extensive areas of apparently suitable habitat, such as those in Rio Grande do Sul and eastern Entre Ríos, have yielded no records (T. A. Parker in litt. 1992, Pearman and Abadie 1995), and within Emas National Park, clearly one of its strongholds, the species seems to be confined to a few small areas, the entire population (if resident) being judged very small, "doubtfully exceeding a few hundred individuals" (T. A. Parker in litt. 1992).

This seeming patchiness is mirrored in the historical record. At Santa Elena in Uruguay in November 1992 only two were encountered (Aplin 1892), yet in the same month of the same year at another Santa Elena, in Argentina, it was "fairly common" (Holland 1893); and although at Sapucaí, Paraguay, the single bird collected was the only one encountered in a three-year period (Chubb 1910), it was "not rare" in late 1883 in Paysandú, Uruguay (Gibson 1885).

The size and behaviour of the Bearded Tachuri may be a significant influence in general assessments of its status. Despite their concern that it may be 
threatened, Ridgely and Tudor (1994) admit that it is inconspicuous and therefore "probably often overlooked", and two recent observers of the race brevipennis independently approach this conclusion. In Venezuela M. Kessler (in litt. 1994) obtained his April 1994 records casually during botanical work, and therefore tentatively suggests that the species may not be rare in the central Gran Sabana. In Colombia F. G. Stiles (in litt. 1994) "was impressed with what a difficult bird it is to see from any distance", as "it rarely perches as much as a metre above the ground or water and its sallies are likewise short and low"; he too speculates that it may not really be rare so much as greatly overlooked. There is, moreover, the important testimony of Holland (1893), quoted above, which indicates precisely the same habits in the race pectoralis (and emphasizes the temporally patchy nature of its unobtrusiveness), and of one observer in Emas National Park who refers to the species's habit of keeping low in vegetation and being frequently lost to view (R. Schofield in litt. 1994). On one occasion a bird was observed actually spending time on the ground, although also often clinging to grass stems near the ground (R. Hopf in litt. 1994).

Changes in the status of the Bearded Tachuri must inevitably have occurred over the past century. Although there are areas which appear to remain as yet unaffected by human development (Meta is one: F. G. Stiles in litt. 1994), Fjeldså and Krabbe (1990) report that the species's savanna habitat is being destroyed everywhere, Ridgely and Tudor (1994) indicate that overgrazing and frequent burning has reduced such habitat to a few scattered sites, and F. E. Hayes (in litt. 1991) identifies the problem in Paraguay as the loss of pristine grassland to agriculture and livestock grazing. More general accounts of the loss of habitat within the bird's range are in Bucher and Nores (1988), Cavalcanti (1988), Fjeldså (1988), and Willis and Oniki (1988). Nevertheless, cases where the Bearded Tachuri has indisputably suffered decline or local extinction are few, and this reflects the general dearth of information on the modern status of South American grasslands. There is the loss of J. Natterer's site, Calção do Couro, to urban expansion in São Paulo (see above), and the San Martín maté plantation in Misiones, Argentina, now flooded by a reservoir (J. C. Chebez in litt. 1995). There is the endangerment and possible extinction of the Andean race bogotensis (see below). Recent searches by T. A. Parker (in litt. 1992) in remnant, but seriously degraded grasslands around Santa Cruz, Bolivia, were unsuccessful, and in his experienced view the present status and future of the Bearded Tachuri "would appear to mirror the situation of the Greater Prairie Chicken Tympanuchus cupido in the Great Plains of North America, that is, both are species that occur in numerous, widely scattered populations that survive (primarily) in suboptimal habitats".

The most unequivocally threatened population of the species is on the montane plateau of Colombia. The statement that bogotensis has not been found at all in over 50 years (Ridgely and Tudor 1994) appears to be based on a similar one made 15 years earlier by King (1978-1979), who was evidently using the date of the most recent publication in his reference list on the species (Cory and Hellmayr 1927) to establish this time-lapse. In fact, F. G. Stiles (in litt. 1994) reports two specimens in the Museo de la Salle, Bogotá, apparently collected in the 1950s, and has twice seen small brown flycatchers in remnant marshes in the Bogotá area, too distant to identify, although J. Fjeldså searched for it in 
1981 without success (in Collar and Andrew 1988). It is clear that if indeed any birds of this race survive their numbers must, as King (1978-1979) stated, be very small. Although King (1978-1979) expressed mystification as to the cause of its rarity, Fjeldså (1988) blamed extensive drainage and conversion of habitat (factors of equal significance in the loss of the Colombian Grebe Podiceps andinus and the endangerment of the Bogotá Rail Rallus scmiplumbus and Apolinar's Wren Cistothorus apolinari: see Collar et al. 1992).

\section{Evaluation of conservation status}

Since the inception of IUCN's Red Data Book programme in the mid-1960s, qualitative criteria provided compilers of information with guidelines for the listing and categorization of taxa. These criteria, with their unspecific reference to impending extinction, near futures and likelihood of deterioration, remained fairly constant over the 20-year period 1974-1993, during which time the opportunity to classify the Bearded Tachuri as threatened arose three times (in King 1978-1979, Collar and Andrew 1988, and Collar et al. 1992), and was accepted only on the second occasion, in the course of a very preliminary and cursory review. The fuller evidence assembled during 1991-1992 suggested that this listing was mistakenly cautious: with populations spread across so large an area of South America, particularly when some of these appeared relatively secure, little justification appeared to exist for believing that the species was as yet in danger of global extinction or likely to reach that condition in the "near" future. Given, however, the many references to its scarcity and to the loss of so much of its habitat, it was clearly a serious cause for concern and hence a candidate for continuous monitoring, a circumstance for which the unofficial but very practical category "near-threatened" had been developed (Collar and Stuart 1985: 708, Collar and Andrew 1988: xi-xii, Collar et al. 1992: 1047, 1994: 222).

During the early 1990 s explicit, quantitative criteria were developed by IUCN against which to measure the conservation status of species. Since in the process of becoming extinct a species must inevitably decline in numbers and contract in range, numerical thresholds were established to promote a more consistent and objective classification of extinction risk using these variables. In the new criteria, the three (alternative) key thresholds dividing "threatened" from "nonthreatened" are $<10$,ooo for the number of mature individuals (this number must also be currently in decline), $<20,000 \mathrm{~km}^{2}$ for the extent of their occurrence (which again must be diminishing), or a rate of decline, irrespective of absolute population size, in excess of $20 \%$ over 10 years. Collar et al. (1994) give an abbreviation of these criteria, which are fully set forth in Mace and Stuart (1994), although the final version adopted by IUCN - containing the rate of decline as expressed above - remains to be published.

There is clearly no question that the Bearded Tachuri fails to meet the rangesize threshold, and we think it reasonable to assume that so small a bird extending over so massive a range must possess more than 10,000 mature individuals: to use the kind of argument deployed by Remsen (1995, this issue), even a density of only one pair per $5 \mathrm{~km}^{2}$ would be enough to reach the required level in the Gran Sabana alone. Nevertheless, extrapolation based on local densities (even if any such data were available) is unwise for very patchily distributed 
species; moreover, as many of the localities detailed under Distribution must by now be lost, any judgement of total population size will be undisguisably purblind. As for a decline of $20 \%$ in the past 10 years (or projected for the next 10 years), this is less likely to be measured in terms of numbers, especially for less frequent tropical species, than by inference from considerable circumstantial evidence. In this case, despite specific examples of habitat loss within the bird's range, it remains doubtful (to us) that such an average can have been achieved or is likely to apply. A more appropriate classification seems to be "nearthreatened", since it would be far less easy to deny (say) a $10 \%$ decline over the last or next 20 years, or (say) a population of $<20$,ooo mature individuals.

However, if the three subspecies are (a) accepted as such (see Taxonomy below) and (b) subjected independently to these criteria (since the criteria can be applied to both species and subspecies), the form bogotensis would clearly qualify at once, as indeed it had already done under the old criteria in King (1978-1979), and it might well be that pectoralis and, with the application of "responsible pessimism" (Collar et al. 1994: 17-18), conceivably even brevipennis could each also be assigned threatened status. This circumstance highlights one of the curiosities of any evaluation system: that the criteria may admit every subspecies of a species even while rejecting the species itself. It might then be asked if it is right that, when threatened subspecies are sufficiently disjunct in range or distinct in ecology from each other for their fates to be entirely independent, the sum of their separate numbers or ranges should disqualify the species as a whole from sharing their status. Against this it can be argued that the probability of extinction must diminish with increasing number of populations (taxonomically distinct or not), and that the fate of the species must be evaluated against a set of absolutes if significant distortions are not to enter the system.

Another area of debate concerns the weight to be given to existing conservation measures for a species, most notably the (usually accidental) protection achieved through its occurrence in parks and reserves. The new criteria include the (non-threatened) category "Conservation Dependent" for species whose fate is directly linked to the continuation of programmes of active management. This is clearly not the case for the Bearded Tachuri, but it may yet be so if, over the coming century, conservation policy for grassland species becomes more fully integrated with agricultural development programmes.

Currently, however, the species is inadequately represented within the existing network of protected areas. Although we cannot be sure that some of the sites listed under Distribution above are not protected, the only ones known to be so are as follows: (Venezuela) Canaima National Park $(3,000,000$ ha) which embraces most of the records from the tepui region (IUCN 1992); (Surinam) Sipaliwini Nature Reserve (100,000 ha), also important for the threatened Rufous-sided Pygmy-tyrant Euscarthmus rufomarginatus (Wege and Long in prep.); (Brazil) Tumucumaque Indigenous Park, Pará $(2,700,000$ ha), which is contiguous with Sipaliwini Nature Reserve (IUCN 1992); Chapada dos Guimarães National Park, Mato Grosso (33,00o ha: IUCN 1992); Emas National Park, Goiás (131,868 ha) which is important for seven threatened bird species including Lesser Nothura Nothura minor (Wege and Long in prep.); Itirapina State Ecological Station $(2,300 \mathrm{ha})$, one of the largest remaining fragments of "campo 
cerrado" in São Paulo, important for the threatened Lesser Nothura and Rufoussided Pygmy-tyrant (Wege and Long in prep.) and also the near-threatened Sharp-tailed Grass-tyrant, Cock-tailed Tyrant, White-banded Tanager Neothraupis fasciata and White-rumped Tanager Cypsnagra hirundinacea (Collar et al. 1992); (Paraguay) Reserva Natural del Bosque Mbaracayú $(62,979$ ha) which supports populations of nine threatened species (Wege and Long in prep.); Reserva Tatí Jupí (no information); (Argentina) the new Mburucuyá National Park, important for four threatened species (Wege and Long in prep.); Costañero del Sur Natural Park (74,00o ha) (IUCN 1992); Bañados del Río Dulce and Mar Chiquita Natural Park (50,00o ha), also important for three threatened species (Wege and Long in prep.); and Otamendi National Scientific Reserve (2,632 ha: IUCN 1992).

\section{Taxonomy}

There is confusion over the distinctiveness of the subspecies of Polystictus pectoralis. In view of Fjeldså and Krabbe's (1990) remark that the northern subspecies, being very small and with no distinct throat markings, may be specifically distinct from nominate pectoralis, we briefly review opinions on the taxonomy of the species, as the subject clearly bears on conservation decision-making (see above). Some of these issues may in due course be illuminated by a study of the little known and, according to R. S. Ridgely (in litt. 1995), infrequently heard voice of the species from various parts of its range.

In fact Sclater (1888) and then the describers of brevipennis, von Berlepsch and Hartert (1909), were fairly emphatic in finding no differences in lowland birds north of the Equator from those to the south other than in size (the measure of which was in the wing, tail and bill). It was Cory and Hellmayr (1927) who considered that brevipennis differs from pectoralis not only by smaller size and feather length but by less developed crest, and less black on cheeks and throat. Even so, such features advance no real case for the separation of brevipennis from pectoralis at the species level: the distinction may be one that chiefly reflects migratory (longer wings) as against sedentary status (in this regard it would worth checking if all nominate pectoralis wing-lengths fall outside the range for brevipennis, or whether the more northerly populations of pectoralis, at least some of which may not be migratory, approach brevipennis in this character).

The situation is complicated by variation within brevipennis itself. Novaes (1967) noted more black to the chin and throat and a more ferruginous wash to the rump in birds from Pará than in one from Roraima, Brazil. Four FMNH birds from Meta, Colombia, are much darker crowned and darker faced than (other) birds from Roraima, Brazil (D. F. Stotz in litt. 1995). Five AMNH birds from lowland Annai ( $96 \mathrm{~m}$ according to Stephens and Traylor 1985), Guyana, are generally paler (almost whitish on the throat and centre of belly) than five birds there from upland Cerro Roraima, Venezuela, some or all of which were collected at over $1,000 \mathrm{~m}$, and one of which (236801) is so saturated as to be barely distinguishable from bogotensis (T. S. Schulenberg in litt. 1995).

This finding further confuses the case of bogotensis, suffering as it does from the paucity and dispersion of the museum material on which it is based. Chap- 
man (1915, also 1917), using a single male, referred to its being "more richly colored throughout" (its size being between pectoralis and brevipennis), and because it was "a form of a Tropical Zone species apparently isolated on the Temperate Zone Savanna of Bogotá", he was tempted to treat it as a full species. Wetmore (1926) took this view, citing not only the "much more rufescent coloration" of bogotensis but also its "wholly black bill, so that it seems to represent a distinct species". Cory and Hellmayr (1927) added that bogotensis is nearest to pectoralis and about the same size, but with crown feathers much more elongated and narrower, back much more tawny, wing bands and edges of remiges deep tawny instead of tawny ochraceous, superciliaries bright buff instead of pure white, and so on.

However, these latter reported no difference between representatives of pectoralis and the single female bogotensis that Hellmayr was able to inspect and which, in fact, he only assumed to be ascribable to bogotensis on the basis of its provenance (Dagua). The variation within brevipennis, in particular the convergence of some specimens on bogotensis, suggests that the situation is more complex than the current arrangement allows, and that much more work is needed before particular features can be identified as the basis for a constant racial character. For example, the significance attached by Wetmore to the black bill of bogotensis is lost alongside Sclater's description of pectoralis's bill as "black above, slate below ${ }^{r}$. Clearly as it stands the evidence of the specific distinctiveness of bogotensis is wanting.

There also appears to be some variation within nominate pectoralis. The taxon Pachyramphus minimus was shown by Hellmayr (1925) to be invalid, although it was judged a distinct race of pectoralis by Allen (1889), basing himself on Gould's (misleading) plate, which is merely an adult male "in high plumage". Nevertheless, Wetmore (1926) found a female taken by T. J. Page on the Paraná (the Irarana bird) to be browner on the underparts and larger in bill than another from Puerto Pinasco, Paraguay; and Cory and Hellmayr (1927) speculated that birds from Brazil might never be so black about the head as those from the other countries in the race's range. There has, however, been no subsequent move to separate any populations of nominate pectoralis as distinct subspecies.

There are two conclusions to draw from this brief review. The first is that it is inappropriate to continue to promote the idea of specific identity for any of the races of Polystictus pectoralis without the assembly and rigorous analysis of an extensive series from all parts of its range. Even the subspecific identities of bogotensis and brevipennis need further study and validation. The second is that the discipline of wildlife conservation cannot function independently of the discipline of formal taxonomy. The extensive list of institutions furnishing specimen data for this study (see Appendix below) is one token of the relevance of museums to conservation; but the fact that we still cannot be sure which taxa compose the subject of this paper illustrates the cardinal importance of continued biological and taxonomic investigation by museums. It is taxonomists on whom conservationists depend for the knowledge of what there is to be conserved. Modern conservation requires working museums. In one real sense, therefore, the fate of the Bearded Tachuri itself is linked, ultimately, to the fate of the institutions that hold the material evidence for its existence. 


\section{Acknowledgements}

All curators and assistants at the museums whose label data are cited in this paper are warmly thanked for their help and hospitality; K. C. Parkes provided the CM data personally and offered critical commentary on this material. D. F. Stotz critically reviewed the typescript twice, and added his records. T. S. Schulenberg and R. S. Ridgely commented on the typescript, the former also furnishing label data from $\mathrm{AMNH}$ and the latter adding his records. $\mathrm{M}$. Pearman furnished label data from MACN and all his records from Argentina. F. E. Hayes supplied the great majority of locality records from Paraguay, R. P. Clay and J. C. Lowen supplementing them. M. Babarskas, J. C. Chebez, B. M. López Lanus, M. Nores and D. Yzurieta provided important material from Argentina, and E. Bucher helped with several points. F. G. Stiles contributed data from Colombia. L. P. Gonzaga, M. L. Goodwin, G. F. Mees and E. O. Willis each added material at various stages. D. K. Dacol, B. C. Forrester, R. Hopf, M. Kessler, R. Ryan, R. Schofield, H. W. Wallis, A. Whittaker and B. E. Wright responded to the request made in Cotinga 1: 48 for their records. M. J. Crosby, G. M. Mace and A. J. Stattersfield reviewed part of the typescript. Librarians F. E. Warr (BMNH), L. Giddings (Royal Society for the Protection of Birds) and A. Rawlins (University Library Map Room, Cambridge) responded promptly to requests for help. We acknowledge the great kindness of all these people.

\section{Appendix}

AMNH $=$ American Museum of Natural History; ANSP = Academy of Natural Sciences of Philadelphia; $\mathrm{BMNH}=$ Natural History Museum, Tring, U.K.; $\mathrm{CM}=$ Carnegie Museum of Natural History; $\mathrm{CMN}=$ Canadian Museum of Nature; $\mathrm{COP}=$ Colección Ornitológica Phelps, Caracas; FMNH = Field Museum of Natural History; IND = Unidad Investigativa Federico Medem, INDERENA, Bogotá; LSUMZ = Louisiana State University Museum of Natural Science; $\mathrm{MCZ}=$ Museum of Comparative Zoology; MHNG= Muséum d'Histoire Naturelle, Geneva; MNHNM = Museo Nacional de Historia Natural, Montevideo; MNRJ = Museu Nacional, Rio de Janeiro; MPEG = Museu Paraense Emílio Goeldi; MZUSP = Museu de Zoologia, Universidade de São Paulo; RMNH = Rijksmuseum van Natuurlijke Historie, Leiden; ROM = Royal Ontario Museum; $U M M Z=$ University of Michigan Museum of Zoology; UNP = Universidad Nacional de la Plata; USNM = United States National Museum; YPM = Peabody Museum, Yale University; ZSM = Zoologische Staatssammlung, Munich.

\section{References}

Allen, J. A. (1889) Descriptions of new species of South American birds, with remarks on various other little known species. Bull. Amer. Mus. Nat. Hist. 2: 137-151. 
Allen, J. A. ( 1892 ) On a collection of birds from Chapada, Matto Grosso, Brazil, made by Mr H. H. Smith. Part II-Tyrannidae. Bull. Amer. Mus. Nat. Hist. 4: 331-350.

Aplin, O. V. (1894) On the birds of Uruguay. Ibis (6)6: 149-215.

von Berlepsch, H. and Hartert, E. (1902) On the birds of the Orinoco region. Novit. Zool. 9: $1-134$.

Bertoni, A. de W. (1930) Aves del chaco paraguayo colectadas por Felix Posner en la Colonia "Monte Sociedad" hoy Benjamin Aceval. Revta. Soc. Cient. Paraguay 2(6): 241258.

Brooks, T. M., Barnes, R., Bartrina, L., Butchart, S. H. M., Clay, R. P., Esquivel, E. Z., Etcheverry, N. I., Lowen, J. C. and Vincent, J. (1993) Bird surveys and conservation in the Paraguayan Atlantic Forest. Cambridge, U.K.: BirdLife International (Study Report 57).

Bucher, E. H. and Nores, M. (1988) Present status of birds in steppes and savannas of northern and central Argentina. Pp.71-79 in P. D. Goriup, ed. Ecology and conservation of grassland birds. Cambridge, U.K.: International Council for Bird Preservation.

Cabanis, J. (1878) Ueber eine Sammlung von Vögeln der Argentinischen Republik. J. Orn. 26: 194-199.

Camperi, A. R. (1992) Estudio de una colección de aves de la provincia de Entre Ríos. Honnero 13: 225-229.

Canevari, M., Canevari, P., Carrizo, G. R., Harris, G., Mata, J. R. and Straneck, R. J. (1991) Nueva guia de las aves argentinas. Buenos Aires: Fundación Acindar.

Cavalcanti, R. B. (1988) Conservation of birds in the cerrado of central Brazil. Pp.5966 in P. D. Goriup, ed. Ecology and conservation of grassland birds. Cambridge, U.K. International Council for Bird Preservation.

Chapman, F. M. (1915) Diagnoses of apparently new Colombian birds, IV. Bull. Amer. Mus. Nat. Hist. 34: 635-662.

Chapman, F. M. (1917) The distribution of bird-life in Colombia. Bull. Amer. Mus. Nat. Hist. 36.

Chapman, F. M. (1931) The upper zonal bird-life of Mts. Roraima and Duida. Bull. Amer. Mus. Nat. Hist. 63: 1-135.

Chebez, J. C., Rey, N., di Giacomo, A. and Babarskas, M. (in press) La avifauna del sistema de parques nacionales de la Argentina. Buenos Aires: Editora LOLA.

Chubb, C. (1910) On the birds of Paraguay. Ibis (9) 4 : 53-78, 263-285, 517-534, 571-647.

Chubb, C. (1921) The birds of British Gliana, 2. London: Bernard Quaritch.

Collar, N. J. and Stuart, S. N. (1985) Threatened birds of Africa and related islands: the ICBP/ IUCN Red Data Book (Third edition, part 1). Cambridge, U.K.: International Council for Bird Preservation.

Collar, N. J. and Andrew, P. (1988) Birds to watch: the ICBP world checklist of threatened birds. Cambridge, U.K.: International Council for Bird Preservation (Techn. Publ. 8).

Collar, N. J., Gonzaga, L. P., Krabbe, N., Madroño Nieto, A., Naranjo, L. G., Parker, T. A. and Wege, D. C. (1992) Threatened birds of the Americas: the ICBP/IUCN Red Data Book (Third edition, part 2). Cambridge, U.K.: International Council for Bird Preservation.

Collar, N. J., Crosby, M. J. and Stattersfield, A. J. (1994) Birds to watch 2: the world list of threatened birds. Cambridge, U.K.: BirdLife International (Conservation Series 4).

Collar, N. J., Wege, D. C. and Long, A. J. (in press) Patterns and causes of endangerment in the New World avifauna. American Ornithologists' Union (Orn. Monogr.).

Cory, C. B. and Hellmayr, C. E. (1927) Catalogue of the birds of the Americas, Part V. Field Mus. Nat. Hist. Zool. Ser. 13 (Publ. 242).

Cuello, J. and Gerzenstein, E. (1962) Las aves del Uruguay: lista sistemática, distribución y notas. Com. Zool. Mus. Hist. Nat. Montevideo 6(93).

Daguerre, J. B. (1922) Lista de aves coleccionadas y observadas en Rosas. Homero 2: 259-271. 
Fjeldså, J. (1988) Status of birds of steppe habitats of the Andean zone and Patagonia. Pp.81-95 in P. D. Goriup, ed. Ecology and conservation of grassland birds. Cambridge, U.K.: International Council for Bird Preservation.

Fjeldsă, J. and Krabbe, N. (1990) Birds of the high Andes. [Copenhagen:] Zoological Museum, University of Copenhagen, and Svendborg: Apollo Books.

Gibson, E. (1885) Notes on the birds of Paisandú, Republic of Uruguay. Ibis (5)3: 275283.

Gliesch, R. (1930) Lista das aves colligidas e observadas no estado do Rio Grande do Sul. Egatea 15: 276-292.

Gore, M. E. J. and Gepp, A. R. M. (1978) Las aves del Uruguay. Montevideo: Mosca Hermanos.

Gould, J. (1841) Birds. Part III of C. Darwin, ed. The zoology of the voyage of H.M.S. Beagle, under the command of Captain Fitzroy, R.N., during the years 1832 to 1836. London: Smith, Elder and Co.

Hartert, E. and Venturi, S. (1909) Notes sur les oiseaux de la République Argentine. Novit. Zool. 16: 159-267.

Haverschmidt, F. and Mees, G. F. (1994) Birds of Suriname. Paramaribo: VACO Uitgeversmaatschappij.

Hellmayr, C. E. (1925) Review of the birds collected by Alcide d'Orbigny in South America (continuation). Novit. Zool. 32: 175-194.

Hilty, S. L. and Brown, W. L. (1986) A guide to the birds of Colombia. Princeton, N.J.: Princeton University Press.

Holland, A. H. (1893) Field-notes on the birds of Estancia Sta. Elena, Argentine Republic. Ibis (6) 5: 483-488.

IUCN (1992) Protected areas of the world: a review of national systems. Volume 4: Nearctic and Neotropical. Gland, Switzerland, and Cambridge, U.K.: International Union for Conservation of Nature and Natural Resources.

King, W. B. (1978-1979) Red Data Book, 2: Aves. Second edition. Morges, Switzerland: International Union for Conservation of Nature and Natural Resources.

Klimaitis, J. F. and Moschione, F. N. (1987) Aves de la Reserva Integral de Selva Marginal de Punta Lara y sus alrededores. Buenos Aires: Ministerio de Economía de la Provincia de Buenos Aires.

Lopez, P. (1898) Mapa de las comunicaciones postales y telegráficas de la República Argentina. Buenos Aires: Compañia Sud Americana de Billetes de Banca.

Mace, G. and Stuart, S. (1994) Draft IUCN Red List categories. Species 21-22: 13-24.

Martelli, A. (1989) Tachuri canela en Chapadmalal. Nuestras Aves 6(19): 9.

Mees, G. F. (1968) Enige voor de avifauna van Suriname nieuwe vogelsoorten. Gerfaut 58: 101-107.

Meyer de Schauensee, R. M. and Phelps, W. H. (1978) A guide to the birds of Venezuela. Princeton, N.J.: Princeton University Press.

Narosky, S., di Giacomo, A. G. and López Lanus, B. (1990) Notas sobre aves del sur de Buenos Aires. Hornero 13: 173-178.

Narosky, T. and di Giacomo, A. G. (1993) Las aves de la provincia de Buenos Aires: distribución y estatus. Buenos Aires: Asociación Ornitológica del Plata.

Navas, J. R. and Bó, N. A. (1988) Aves nuevas o poco conocidas de Misiones, Argentina. III. Revta. Mus. Arg. Cienc. Nat. "Bernadino Rivadavia" Inst. Nac. Invest. Cienc. Nat., Zool. 15(2): 11-37.

Nores, M. and Yzurieta, D. (1980) Aves de ambientes acuáticos de Córdoba y centro de Argentina. Córdoba: Secretaria de Estado de Agricultura y Ganadería.

Nores, M., Yzurieta, D. and Miatello, R. (1983) Lista y distribución de las aves de Córdoba, Argentina. Bol. Acad. Nac. Cienc. Córdoba 56.

Nores, M., Yzurieta, D. and Salvador, S. A. (1991) Lista y distribución de las aves de Santiago del Estero, Argentina. Bol. Acad. Nac. Cienc. Córdoba 59: 157-196. 
Novaes, F. C. (1967) Sobre algumas aves pouco conhecidas na Amazônia brasileira. Bol. Mus. Paraense Emilio Goeldi, Zool. no.64.

Novaes, F. C. (1978) Ornitologia do Território do Amapá, 2. Publ. Avuls. Mus. Paraense Emilio Goeldi no.29.

Office of Geography (1957) Gazetteer no.35: Paraguay. Washington, D.C.: Department of the Interior.

Office of Geography (1963) Gazetteer no.71: Brazil. Washington, D.C.: Department of the Interior.

Office of Geography (1968) Gazetteer no.103: Argentina. Washington, D.C.: Department of the Interior.

Olrog, C. C. (1979) Nueva lista de la avifauna argentina. Opera Lilloana 27.

Partridge, W. H. (1954) Estudio preliminar sobre una colección de aves de Misiones. Revta. Inst. Nac. Invest. Cienc. Nat. Mus. Arg. Cienc. Nat. "Bernadino Rivadavia" Zool. 3(2): 87-153.

Paynter, R. A. (1982) Ornithological gazetteer of Venezuela. Cambridge, Mass.: Museum of Comparative Zoology.

Paynter, R. A. (1985) Ornithological gazetteer of Argentina. Cambridge, Mass.: Museum of Comparative Zoology.

Paynter, R. A. (1989) Ornithological gazetteer of Paraguay. Second edition. Cambridge, Mass.: Museum of Comparative Zoology.

Paynter, R. A. (1992) Ornithological gazetteer of Bolivia. Second edition. Cambridge, Mass.: Museum of Comparative Zoology.

Paynter, R. A. (1994) Ornithological gazetteer of Uruguay. Second edition. Cambridge, Mass.: Museum of Comparative Zoology.

Paynter, R. A. and Traylor, M. A. (1981) Ornithological gazetteer of Colombia. Cambridge, Mass.: Museum of Comparative Zoology.

Paynter, R. A. and Traylor, M. A. (1985) Ornithological gazetteer of the Guianas. Cambridge, Mass.: Museum of Comparative Zoology.

Paynter, R. A. and Traylor, M. A. (1991) Ornithological gazetteer of Brazil. Cambridge, Mass.: Museum of Comparative Zoology.

Pearman, M. and Abadie, E. (1995) Mesopotamia grassland and wetlands survey 19911993: conservation of threatened birds and habitat in north-east Argentina. Unpublished report.

von Pelzeln, A. (1868-1871) Zur Ornithologie Brasiliens: Resultate von Johann Natterers Reisen in den Jahren 1817 bis 1835. Wien: A. Pichler's Witwe und Sohn.

Pereyra, J. A. (1923) Las aves de la región ribereña de la Provincia de Buenos Aires. Hornero 3: 159-174.

Pereyra, J. A. (1933) Miscelánea ornitológica. Homero 5: 215-219.

Pereyra, J. A. (1938) Algunos nidos poco conocidos de nuestra avifauna. Homero 7: 24-30.

Peters, J. L. (1923) Dos aves nuevas para la fauna mendocina. Hornero 3: 197-198.

Phelps, W. H. and Phelps, W. H. (1963) Lista de las aves de Venezuela con su distribución, Parte II: Passeriformes. Secunde edición. Bol. Soc. Venezolana Cienc. Nat. 24.

Pinto, O. M. de O. (1944) Catálogo das aves do Brasil. 2a Parte. São Paulo: Departamento do Zoologia.

Pinto, O. M. de O. (1966) Estudo crítico e catálogo remissivo das aves do Território Federal de Roraima. Caderno de Amazônia 8.

Remsen, J. V. (1995) The importance of continued collecting of bird specimens to ornithology and bird conservation. Bird Conserv. Internatn. 5: 145-180.

Ridgely, R. S. and Tudor, G. (1994) The birds of South America, 2: the suboscine passerines. Austin, Texas: University of Texas Press.

Salvadori, T. (1895) Viaggio del dott. Alfredo Borelli nella Repubblica Argentina e nel Paraguay: uccelli raccolti nel Paraguay, nel Matto Grosso, nel Tucuman e nella Provincia di Salta. Boll. Mus. Zool. Torino 10 (no.208). 
Salvin, O. (1885) A list of the birds obtained by Mr Henry Whitely in British Guiana. Ibis 5(3): $291-306$.

Sclater, P. L. (1879) [A small collection of birds . . . by Dr Adolf Döring.] Proc, Zool. Soc. Lond : $460-461$.

Sclater, P. L. (1888) Catalogue of the birds in the British Museum, 14. London: Trustees of the British Museum.

Sclater, P. L. and Hudson, W. H. (1888) Argentine ornithology, 1. London: R. H. Porter. Short, L. L. (1975) A zoogeographic analysis of the South American chaco avifauna. Bull. Amer. Mus. Nat. Hist. 154: 165-352.

Short, L. L. (1976) Notes on a collection of birds from the Paraguayan chaco. Amer. Mus. Novit. 2597.

Sick, H. (1993) Birds in Brazil: a natural history. Princeton, N.J.: Princeton University Press.

SOMA = Sección Ornitológica del Museo Argentino de Ciencias Naturales (1935-1942) Lista sistemática de las aves argentinas. Hornero 6: 151-196, 343-364, 531-554; 7: 89124, 299-326, 447-472; 8: 137-153, 309-344.

Steinbacher, J. (1962) Beiträge zur Kenntnis der Vögel von Paraguay. Abhandl. Senckenb. Naturforsch. Ges. 502: 1-106.

Stephens, L. and Traylor, M. A. (1985) Ornithological gazetteer of the Guianas. Cambridge, Mass.: Museum of Comparative Zoology.

Tostain, O., Dujardin, J.-L., Erard, C. and Thiollay, J.-M. (1992) Oiseaux de Guyane. Brunoy: Société d'Etudes Ornithologiques.

Wege, D. C. and Long, A. J. (in press) Key Areas for threatened birds in the Neotropics. Cambridge, U.K.: BirdLife International (Conservation Series 5).

Wetmore, A. (1926) Observations on the birds of Argentina, Paraguay, Uruguay and Chile. Bull. U.S. Natn. Mus. 133: 1-448.

Willis, E. O. (1992) Itirapina, São Paulo, Brazil. Amer. Birds 46: 1021.

Willis, E. O. and Oniki, Y. (1988) Bird conservation in open vegetation of São Paulo state, Brazil. Pp.67-70 in P. D. Goriup, ed. Ecology and conservation of grassland birds. Cambridge, U.K.: International Council for Bird Preservation.

Zimmer, J. T. (1955) Further notes on tyrant flycatchers (Tyrannidae). Amer. Mus. Novit. 1749 .

N. J. COLLAR and D. C. WEGE

BirdLife International, Wellbrook Court, Girton Road, Cambridge $\mathrm{CB}_{3}$ oNA, U.K. 